\title{
Comparison of tumor markers using different detection devices [Retraction]
}

Tao R, Tu SH, Liu C, Yang Q, Zhu M, Shen JF. OncoTargets and Therapy. 2015;8:1083-1090.

The authors respectfully retract this original research article.

"We realize that some of the results referenced in this paper are preliminary analyses and may not reflect the final data and conclusions of the clinical trials cited".

\section{Publish your work in this journal}

OncoTargets and Therapy is an international, peer-reviewed, open access journal focusing on the pathological basis of all cancers, potential targets for therapy and treatment protocols employed to improve the management of cancer patients. The journal also focuses on the impact of management programs and new therapeutic agents and protocols on

\section{Dovepress}

patient perspectives such as quality of life, adherence and satisfaction. The manuscript management system is completely online and includes a very quick and fair peer-review system, which is all easy to use. Visit http://www.dovepress.com/testimonials.php to read real quotes from published authors. 